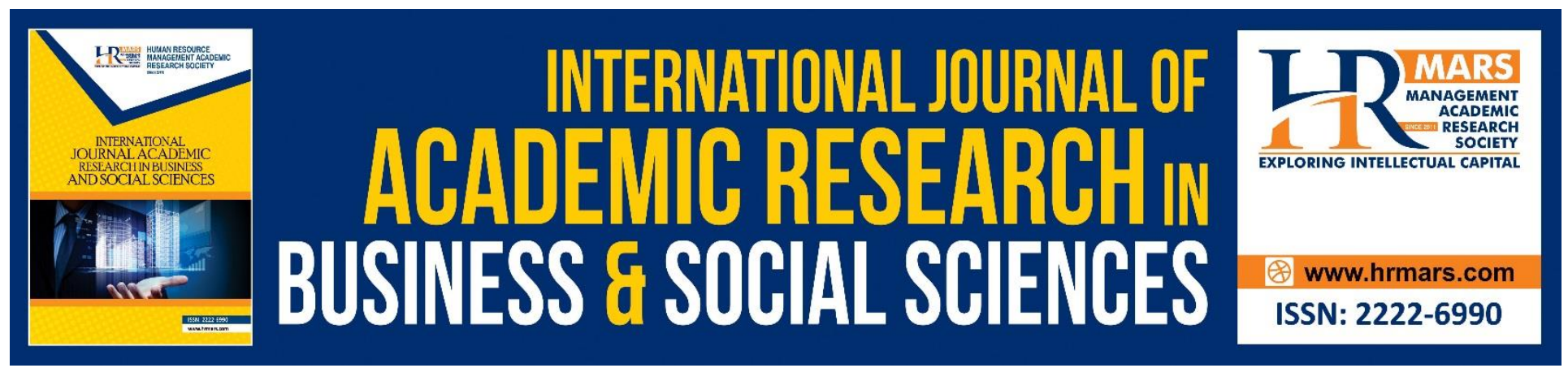

\title{
Quantity Surveyors' Roles and Responsibilities in Different Job Sectors
}

Norazlin Mat Salleh, Edelin Husien, Siti Nurhayati Husin, Nurul Huda Muhammad and Noorlinda Alang

To Link this Article: http://dx.doi.org/10.6007/IJARBSS/v10-i10/8271 DOI:10.6007/IJARBSS/v10-i10/8271

Received: 02 September 2020, Revised: 20 September 2020, Accepted: 17 October 2020

Published Online: 30 October 2020

In-Text Citation: (Salleh et al., 2020)

To Cite this Article: Salleh, N. M., Husien, E., Husin, S. N., Muhammad, N. H., \& Alang, N. (2020). Quantity Surveyors' Roles and Responsibilities in Different Job Sectors. International Journal of Academic Research in Business and Social Sciences, 10(10), 1090-1101.

\section{Copyright: (c) 2020 The Author(s)}

Published by Human Resource Management Academic Research Society (www.hrmars.com)

This article is published under the Creative Commons Attribution (CC BY 4.0) license. Anyone may reproduce, distribute, translate and create derivative works of this article (for both commercial and non-commercial purposes), subject to full attribution to the original publication and authors. The full terms of this license may be seen at: http://creativecommons.org/licences/by/4.0/legalcode

Vol. 10, No. 10, 2020, Pg. 1090 - 1101

Full Terms \& Conditions of access and use can be found at http://hrmars.com/index.php/pages/detail/publication-ethics 


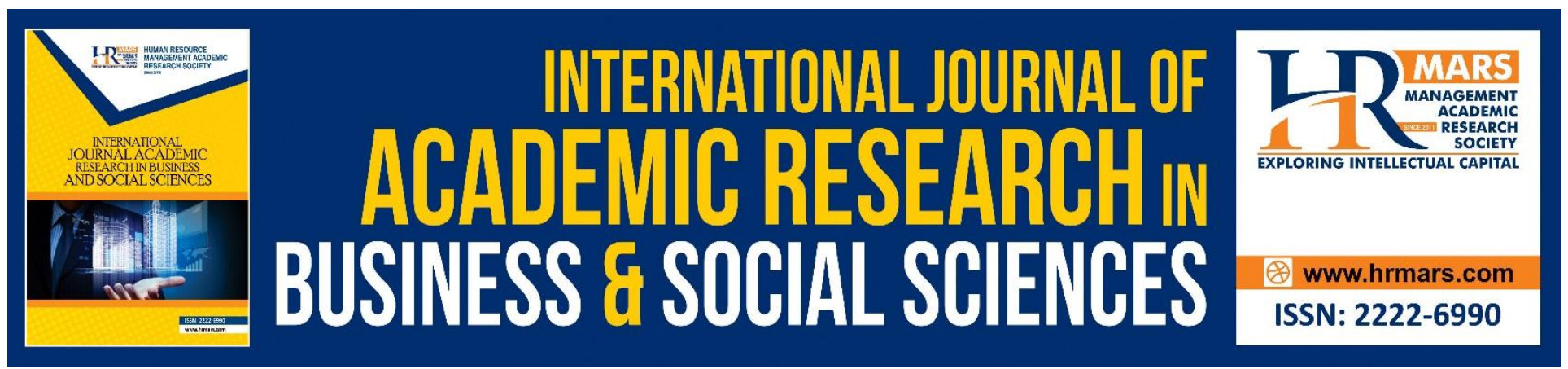

\title{
Quantity Surveyors' Roles and Responsibilities in Different Job Sectors
}

\author{
Norazlin Mat Salleh ${ }^{1}$, Edelin Husien², Siti Nurhayati Husin ${ }^{3}$, \\ Nurul Huda Muhammad ${ }^{4}$ and Noorlinda Alang ${ }^{5}$ \\ 1, 2,3,4 Department of Quantity Surveying, Faculty of Architecture, Planning and Surveying, 32610 \\ Universiti Tekonologi MARA, Perak, ${ }^{5}$ Academy of Language Studies, Faculty of Architecture, \\ Planning and Surveying, 32610 Universiti Tekonologi MARA, Perak
}

\begin{abstract}
Quantity surveying is an essential component in any construction development worldwide and offers services across various industries. In Malaysia, the quantity surveying (QS) profession is managed by the Board of Quantity Surveying Malaysia or BQSM. It is a statutory body established by an Act of Parliament, namely under the Quantity Surveying Act 1967. The QS profession is required from the inception stage of construction and is extended throughout the end of building life. The scope of work is different in every stage of construction project; typically to give advice on the aspects of financial and contract administration. However, people have always wondered about this QS profession and it is undeniably unpopular compared to architects and engineers. Until now, the QS'S roles and responsibilities are still unclear. Hence, this paper aims to present a critical review on the different QS's functions in procurement, oil and gas, green building and banking sectors. Overall, this paper provides useful insights to potential students and individuals who would like to venture into QS world, as well as a guideline for QS novices in different job sectors to better understand their duties and responsibilities.
\end{abstract}

Keywords: Quantity Surveying, Construction, Roles, Responsibilities, Job Sectors

\section{Introduction}

Globally, quantity surveying (QS) is a profession introduced in the United Kingdom since 1859 (Cruywagen \& Llal, 2017). Back then, it was a norm for a project to be executed without measures and values, in fact no bills of quantities (BQ) were produced at that time. A few craftsmen were appointed to complete the job and drawings were only available in a form of sketches. After the job was completed, the craftsmen submitted the estimates for the payment. It was during this time that clients became unsatisfied because they were unable to rationalise the sum of work done and the total amount claimed by the craftsmen which led to overclaims and wastage. This triggered the need to hire a surveyor to check all claims and to ensure the sum of work done was equivalent to the total amount claimed. During the industry revolution in the 19th century, project work became more 
INTERNATIONAL JOURNAL OF ACADEMIC RESEARCH IN BUSINESS AND SOCIAL SCIENCES Vol. 10, No. 10, 2020, E-ISSN: 2222-6990 @ 2020 HRMARS

complicated. The QS profession was highly demanded during this time especially to manage the financial aspect of the project.

Locally, the development of QS profession has begun since 1930. It was developed when a few quantity surveyors from England migrated to Singapore. During that time, they formed first QS consultancy firm named Messrs Water and Watson. In 1951, Maktab Teknik Kulala Lumpur introduced a QS course to equip the locals to become qualified quantity surveyors (Chong, 2014). Indeed, this boosts the number of local quantity surveyors. As can be seen in Table 1, to date there are more than a thousand of quantity surveyors in Malaysia. However, according to Wao and Flood (2016), the QS profession still unpopular compared to architects and engineers. For students who want to enrol in QS courses in universities, people normally question their choice as they do not really see the prospect of this profession. Contrastingly, people easily understand if the students choose to do architecture or engineering. Yet, the QS roles in certain job sectors are still critical (Olanrewaju \& Anahve, 2015). However, Wao (2016) mentioned that in an international construction project involving professionals from different countries, popularity of the quantity surveying profession is depending on the geographical location of the project itself.

Therefore, the objective of this paper is to present the critical review of quantity surveyors' roles and responsibilities in different job sectors. It is hoped that this writing will offer knowledge to novices in this profession with a focus in the procurement, oil and gas, green building and banking sectors. Furthermore, this information is also valuable to academic institutions offering quantity surveying courses, practicing quantity surveyors and other members in the construction industry.

Table 1: Quantity Surveyors in Malaysia

\begin{tabular}{|c|l|c|}
\hline Item & \multicolumn{1}{|c|}{ Quantity Surveyor } & Number \\
\hline 1 & Registered Consultant QS & 652 \\
\hline 2 & $\underline{\text { Registered Professional QS }}$ & 848 \\
\hline 3 & Registered Provisional QS & 2311 \\
\hline 4 & $\underline{\text { Registered QS Technologist }}$ & 20 \\
\hline 5 & $\underline{\text { Registered Consultant QS Practice }}$ & 360 \\
\hline
\end{tabular}

Source: Board of Quantity Surveyors Malaysia (BQSM), July, 2019

\section{Literature Review}

According to Chong (2014), the common traditional roles of quantity surveyors were in preparing BQ and final accounts. The roles were then extended to the construction sector itself, as well as to other sectors including banking. As stated by the Royal Institution Surveyors Malaysia (RISM) (2020), basically professional quantity surveyors offers two categories of services, namely the basic and supplementary.

\section{Basic Services}

The basic services offered by professional quantity surveyors are:

- Preparation of preliminary cost estimates and cost plans of a development project.

- Advice on cost estimates in relation to a project design.

- Advice on procurement, tendering and contract procedures and arrangements. 
INTERNATIONAL JOURNAL OF ACADEMIC RESEARCH IN BUSINESS AND SOCIAL SCIENCES Vol. 10, No. 10, 2020, E-ISSN: 2222-6990 @ 2020 HRMARS

- Preparation of the Bill of Quantities or specification documents for tendering purposes.

- Organise calls for tenders.

- Evaluation of tenders received in the form of tender reports.

- Preparation and execution of a formal contract.

- Interim valuation of works in progress on site for purposes of interim payments.

- Preparation of financial statement of regular intervals during the construction period.

- Settlement of the final accounts of the project.

\section{Supplementary Services}

Professional quantity surveyors also offers the following services:

- Preparation of feasibility studies of a project.

- Projection of estimated project or development expenditure and anticipated income cash flows.

- Evaluation of contractors registered for prequalification.

- Comparative cost studies on the economics of the project during design stage.

- Project management of construction project.

- Life-cycle costing and studies on economics of alternative design.

- Pricing of Bill of Quantities or negotiating and agreeing Schedule of Rates.

- Valuation or auditing of contract claims for arbitrations litigation cases.

- Valuation or auditing of insurance claims for fire damaged buildings.

- Auditing of contracts and their related budgets and expenditure.

- Application of the full scope of quantity surveying services in Turnkey or Privatisation Contracts.

Various research has been conducted about the potential development of a QS profession (Verster, 2006; Wao, 2016; Wao \& Flood, 2016). In particular, Abdullah and Haron (2006) state that the future direction of quantity surveying practice will be influenced by the country's industrialisation drive, structural transformation of the economy, future technology breakthroughs, the significance of information and communication technology (ICT) in future construction activities and increased globalisation of construction markets. Quantity surveyors need to understand their own objectives and the dynamic requirements of project owners in order to explore appropriate and innovative ways to deliver the required value diligently and effectively (Wao, 2016). Furthermore, quantity surveyors in the new millennium need to be more independent and put themselves forward compared to the other professionals in the industry or else their job opportunities will be seized by the others. Therefore, it is vital for quantity surveyors to prepare and equip themselves well and be bold to face intricacies of clients' requirements.

As said by Thayaparan et. al., (2011), the various economic developments, countless studies and technological growths have prompted the roles of quantity surveyors. When these factors were analysed, the results showed that the development trends in the building economics that happened in the end of the twentieth century had significantly impacted and shifted the roles of people in this quantity surveying profession. This situation can be clearly seen in Table 2. Factors like market changes, construction industry and clients' needs were accountable either as threats or opportunities, pushing this quantity surveying profession to change in order to remain relevant in the industry. In its report entitled 'The Challenge of Change', the Royal Institute of Chartered Surveyors (RICS) highlighted the dynamics of this profession, however a warning was also raised to remind 
INTERNATIONAL JOURNAL OF ACADEMIC RESEARCH IN BUSINESS AND SOCIAL SCIENCES Vol. 10 , No. 10, 2020, E-ISSN: 2222-6990 @ 2020 HRMARS

quantity surveyors to accept changes to continue to exist in the future (Powell, 1998). Of late, another skill that they need to master is in the use of information technology and variety of software to ensure that they are more competitive and on a par with the other players in the industry in serving their clients.

Consequently, improved and more prominent roles of quantity surveyors have emerged in keeping with requirements to satisfy clients. They have started to venture into procurement, design cost planning, whole life costing, value management, and risk analysis and management. Before this, to construct a building, the engineering services would lead the way as the emphasis is on measurements, costs and values of such services. Additionally, according to Ashworth and Hogg (2007), quantity surveyors have also involved in the project and construction management, facilities management, contract disputes and litigation. Hence, it is predicted that quantity surveyors will establish more roles in the future in proportion to "client focus, development and application of information and communication technologies, research and its dissemination, graduate capability and practice size" (Thayaparan et. al., 2011). Subsequently, the profession has begun to explore potential roles in sectors like procurement, oil and gas, green building and banking.

Table 2: Chronology of Developments in Building Economics (Ashworth, 2004, p.29)

\begin{tabular}{|c|c|c|c|}
\hline Date & Building Economics & Other Developments & Practice \\
\hline $\begin{array}{l}\text { Pre - } \\
1960 s\end{array}$ & $\begin{array}{l}\text { Building Bulletin: Cost study } \\
\text { (1957) } \\
\text { Building price books RICS } \\
\text { Cost Research Panel }\end{array}$ & Post-war building boom & $\begin{array}{l}\text { Approximate } \\
\text { estimating } \\
\text { Bills of quantities } \\
\text { Final accounts }\end{array}$ \\
\hline $1960 s$ & $\begin{array}{l}\text { Construction Studies of } \\
\text { elements } \\
\text { Cost limits and allowances } \\
\text { Value for money in building } \\
\text { Building } \\
\text { Cost Information Service } \\
\text { The Wilderness Group }\end{array}$ & Cost-benefit analysis & $\begin{array}{l}\text { Elemental bills } \\
\text { Operational bills } \\
\text { Cut and shuffle } \\
\text { Cost planning } \\
\text { Standard } \\
\text { phraseology }\end{array}$ \\
\hline 1970s & $\begin{array}{l}\text { Cost-in-use } \\
\text { Cost modeling } \\
\text { Contractor's estimating } \\
\text { Cost control }\end{array}$ & $\begin{array}{l}\text { Measurement } \\
\text { conventions } \\
\text { Data coordination } \\
\text { Building maintenance } \\
\text { information } \\
\text { Buildability } \\
\text { Value-added } \\
\text { tax/taxation Bidding } \\
\text { strategies Computer } \\
\text { applications } \\
\text { Undergraduate surveying } \\
\text { degrees }\end{array}$ & $\begin{array}{l}\text { Computer bills } \\
\text { Formula methods of } \\
\text { price adjustment } \\
\text { Cash flow } \\
\text { forecasting } \\
\text { Engineering and } \\
\text { construction }\end{array}$ \\
\hline $1980 \mathrm{~s}$ & $\begin{array}{l}\text { Life-cycle costing } \\
\text { Cost data explosion }\end{array}$ & $\begin{array}{l}\text { Coordinated project } \\
\text { information }\end{array}$ & $\begin{array}{l}\text { Project } \\
\text { management }\end{array}$ \\
\hline
\end{tabular}


INTERNATIONAL JOURNAL OF ACADEMIC RESEARCH IN BUSINESS AND SOCIAL SCIENCES Vol. 10, No. 10, 2020, E-ISSN: 2222-6990 @ 2020 HRMARS

\begin{tabular}{|l|l|l|l|}
\hline & $\begin{array}{l}\text { Cost engineering } \\
\text { techniques Accuracy in } \\
\text { forecasting } \\
\text { Value engineering }\end{array}$ & $\begin{array}{l}\text { Procurement systems } \\
\text { European comparisons } \\
\text { Construction industry } \\
\text { analysis } \\
\text { Postgraduate education } \\
\text { Single-point } \\
\text { responsibility }\end{array}$ & $\begin{array}{l}\text { Post-contract cost } \\
\text { control Contractual } \\
\text { procedures } \\
\text { Contractual claims } \\
\text { Design and build }\end{array}$ \\
\hline 1990s & $\begin{array}{l}\text { Value management } \\
\text { Risk analysis } \\
\text { Quality systems } \\
\text { Expert systems }\end{array}$ & $\begin{array}{l}\text { Facilities management } \\
\text { Commercial revolution } \\
\text { Single European market } \\
\text { Building sustainability } \\
\text { Information technology }\end{array}$ & $\begin{array}{l}\text { Fee competition } \\
\text { Diversification } \\
\text { Blurring of } \\
\text { professional } \\
\text { boundaries } \\
\text { Development } \\
\text { appraisal }\end{array}$ \\
& $\begin{array}{l}\text { Benchmarking } \\
\text { Added value in building and } \\
\text { design } \\
\text { Whole-life costing }\end{array}$ & $\begin{array}{l}\text { IT in construction } \\
\text { Knowledge management }\end{array}$ & $\begin{array}{l}\text { Rethinking } \\
\text { construction } \\
\text { Lean construction } \\
\text { Facilities } \\
\text { 2000s }\end{array}$ \\
\hline
\end{tabular}

\section{Methodology}

The review of literature was done by scrutinizing and analysing journal papers, conference proceedings, and other publications from 2005 to 2019. A search was carried out by using Google Scholar and Mendeley literature search. The keywords 'roles of quantity surveyors' were used in the search and the Google Scholar have identified 37,400 potentially relevant references, however only certain appropriate papers and articles were selected to be reviewed. In addition, the keywords 'roles of quantity surveyors AND procurement' have detected 21,600 results, 'roles of quantity surveyors AND green building' detected 24,400 results and 'roles of quantity surveyors AND procurement' detected 19,600 results. It was also found that similar papers appeared more than once since the keywords applied were 'quantity surveyors.' Although there are numerous research has been done regarding a QS profession, only a few papers were selected to be reviewed for this research, particularly the ones pertaining to field procurement, oil and gas, green building and banking sectors.

\section{QS Profession in Green Construction}

In Malaysia, about $40 \%$ of new buildings are adopting green building initiatives by planning and designing buildings that are more energy-efficient with zero carbon emission. Professional quantity surveyors need to adapt with the new trend of green construction. The traditional roles of quantity surveyors have developed to accommodate this new green buildings trend. These changing roles in relation to green buildings include sustainability strategy development, life cycle cost appraisal, consulting on green star system, advising on engineering services solutions, and valuing sustainability of a property (Ma \& Luu, 2013). 
INTERNATIONAL JOURNAL OF ACADEMIC RESEARCH IN BUSINESS AND SOCIAL SCIENCES Vol. 10, No. 10, 2020, E-ISSN: 2222-6990 @ 2020 HRMARS

Ma and Luu also add that in a green project, quantity surveyors provide not only advice to clients or developers to establish their sustainability targets, but also the comparable information of alternatives to the design team. This is significantly crucial in selecting the most cost effective option for a sustainable design. In order to effectively deliver cost advisory services for green projects to clients and other industry professionals, quantity surveyors are required to progressively develop their skills and knowledge. It has been revealed that an understanding of green products and materials is one of the key advantages for them to remain relevant in the profession (Ma \& Luu, 2013).

Seah (2009) agrees on this matter as he states that current quantity surveyors should equip themselves with necessary skills and competencies to ride the next global wave of sustainable development in order to remain relevant in the industry. Aside from their traditional roles, quantity surveyors in this new era should be ready to accept various new and exciting challenges. Seah has also identified the followings as the expanded role of quantity surveyors in green building projects:

- Green costing - Knowledge of new and emerging technologies that are being utilized in green buildings and their related costs.

- Carbon Footprint - The first step in developing a carbon management strategy for buildings will be to accurately measure the current level of carbon emissions.

- Life Cycle Costing or Life Cycle Assessment - The field of Life Cycle Costing (LCC) will get more emphasis in the next few years and quantity surveyors should be ready to handle this role as they are expert in cost management.

- Property Performance Reporting - The emphasis on energy efficiency and the changing demand of today's tenants require building owners to work their way through the existing performance measurement tools to understand where they fail to meet new standards.

- Green Building Rating Assessment - With a greater understanding of the green building rating systems, quantity surveyors should be able to advise clients on costing and sustainable designs.

- Building Information Modelling (BIM) is an integral platform for the management of information throughout the project lifespan. The BIM model is suitable to be used when visual presentation is required.

In his case study of the Khoo Teck Puat Hospital (KTPH) Singapore, which is owned by the Ministry of Health (MOH), that completed its construction in 2010 at the cost of approximately S\$700 million, Wong (2017) finds that the roles of quantity surveyors with green designs expertise are: as an assisting team to set realistic budget, to be aware of current market condition; to help the team with choices that may keep costs under control; to assist the team with life cycle cost analysis and to ensure both costs and credits for green features are accounted for; to assist the team in updating cost estimates; and to review final bid documents with the design team. Additionally, quantity surveyors also provide cost estimates for each design iteration and conduct value engineering (VE) studies. In order to play their expanded role effectively in green buildings projects, competent quantity surveyors must understand the criteria of green buildings, green designs and integration (including green products and technologies) and the green costing (engineering values). 
INTERNATIONAL JOURNAL OF ACADEMIC RESEARCH IN BUSINESS AND SOCIAL SCIENCES Vol. 10, No. 10, 2020, E-ISSN: 2222-6990 @ 2020 HRMARS

\section{QS Profession in Procurement}

According to Jalil et al., (2017) procurement system in construction is defined as a process to organise and coordinate the related parties in the project, especially in defining their contract relationship which includes the contract responsibility, duties that every party has, their rights, liabilities and roles towards the project. Moreover, procurement is a significant factor in the overall success of a project and it is a process used to accomplish construction projects within the budget, time duration, and required qualities by deciding the overall project framework, responsibilities, structure and authorities of the project main parties. Recently, there are many new procurement systems introduced, and quantity surveyors need to understand these systems to be skilful in procurement matters.

However, within the last decade, there has been a shift in approaches to procurement (Preece et al., 2008). The environment for quantity surveying practice has changed along with the country's rapid economic development (Abdullah and Haron, 2006). A decline in the use of the traditional method of procurement presents several challenges for the QS profession (Preece et al., 2008). In their research, Jalil et al. (2017) state that as the industry developed, modern and alternative procurement systems have been introduced, such as 'Design and Build' management fees. 'Design and Build' is the new integrated procurement system that places the main responsibility to the main contractors to design and construct the project, and they will also be responsible from the beginning until the completion of the project (Jalil et al., 2017). Many projects adopt this procurement system because it allows new requirements to be implemented, such as clients' involvement in the project, allows fast track construction as the detailed designs can be made after the trade contractors are appointed, the clients can choose either to appoint the trade contractors directly or indirectly and more activities can be overlapped, thus allowing time saving (Jalil et al., 2017). As a result, new quantity surveyors roles are developed with a focus on risk management, value management, legal and environmental services as a response to changes demanded by the major procuring clients (Preece et al., 2008).

Olanrewaju and Anahve (2015), from their research on duties and responsibilities of quantity surveyors in the procurement of building services engineering involving 69 quantity surveyors, engineers, architects, estate managers and town planners, reveal eight roles of quantity surveyors. The roles are to offer advice in the preliminary architectural development on the impact of the building envelope design, provide input into the project's cost plan through the establishment of capital budget, provide services on the whole life costs, provide an environmental impact assessment, examine the impact of contract arrangement, provide cost control during the construction, provide input into the establishment of the project brief, conduct value management and provide input into the development of specification clauses.

\section{QS Profession in Oil and Gas}

According to Malaysian Investment Development Authority (MIDA), oil and gas industry continues to play a significant role in the economic development of Malaysia. A total of 32 projects with the total investment of RM25.18 billion were approved by MIDA in 2016. These projects are expected to create 1,539 employment opportunities in the oil and gas sector including for QS profession. This profession is common in building construction sector but not in oil and gas sector, just like people normally relate 
INTERNATIONAL JOURNAL OF ACADEMIC RESEARCH IN BUSINESS AND SOCIAL SCIENCES Vol. 10, No. 10, 2020, E-ISSN: 2222-6990 @ 2020 HRMARS

engineering students to engineering projects (Odesanya \& Ebhohimen, 2017). Oil and gas industry is a large-scale international petrochemical industry which exists in Malaysia. It has risen from being relatively small, through the stage of being one of many largest industries, to a position where the whole economies are profoundly influenced by the need for and price of petroleum products (Hanid et. al., 2007).

Hanid et. al., (2007) add that activities in the petroleum sector can be divided into upstream and downstream; upstream activities are efforts of exploration and production while the downstream activities are refining, marketing and distribution of the petroleum. However, the roles in the petroleum sector can be divided into technical and commercial; technical roles include geosciences, health, safety and environment, quality management, project management and engineering, whereas commercial roles comprise of finance and accounting, cost engineering and estimating, business planning and development, marketing and training, contracting and commercial, legal, procurement, human resource, administration, information technology and supply and distribution (Hanid et. al., 2007).

Odesanya and Ebhohimen (2017) have listed nineteen roles of quantity surveyors in oil and gas projects based on his study involving forty 45 quantity surveyors in Nigeria. The roles are listed according to their rank; the higher ranking are Cost Estimator, Cost Engineer, Total Cost Manager, Procurement Planning Manager, Contract Manager, Risk Manager, Cost Planning Manager, Value Analysis and Engineering Manager, Budgeting Manager, Resource Manager, Asset and Facility Manager, Project Implementation and Performance Manager, Planning Manager, Assessment Manager, Investment Feasibility Manager, Arbitrator, Technical Auditor, Supply and Distribution Manager. The lowest ranking is Health, Safety and Environment Manager. Odesanya and Ebhohimen later conclude that the roles of quantity surveyors in oil and gas industry are still in the average level. Therefore, they need to put extra efforts to understand more about oil and gas industry.

\section{QS Profession in Banking}

Financial institutions are deemed important in the development of a country as a huge capital is required to start the development. According to Kalpana and Rao (2017), some important roles of banks in the development of a country are promoting people's saving habits, offering capital and promoting industries, facilitating trade and commerce functions, generating employment opportunities and supporting the development in various sectors. Some banks hire quantity surveyors to deliver their professional services but the small number of them in this sector make it difficult to retrieve the statistic. In future, there are prospects for quantity surveyors to secure jobs in insurance or other finance positions in banks, or as corporate finance officers (Zainudin et al., 2006). Generally, the construction industry will work closely with banks for housing loans, developer or project loans and technical appraisal. Thus, the roles of quantity surveyors in financial institutions are to assess the technical appraisals from the followings: construction stakeholders who need the capital, developers who want to develop a new project, contractors who want to bid for a new project, suppliers who want to produce a new material and individuals who want to buy a house or other properties.

As described by Perera et al. (2007), housing loans are funding for individuals to fulfil their housing requirements including to build their own house, to buy a new or used house or to renovate 
the existing house. Besides, funding for developer is called a project loan and is offered to developers to assist them in dealing with property development or large scale housing projects. Handling of these loans are done only by certain housing banks or housing finance units of commercial banks. These banks and units will evaluate three aspects of the borrowers and the proposed projects including credit appraisals for the borrowers, and legal and technical appraisals for the proposed projects. All of these appraisals are done separately and independently.

Additionally, banks also need to determine values of properties to be mortgaged or forced sale values of proposed properties to be guaranteed. This is the fundamental requirement to secure the credit. A technical appraisal is required to ascertain the above values and is carried in several steps. Initially, a valuation need to be carried out for the proposed projects according to the sound valuation principals, then proposed developments need to be estimated. For that, a technical appraiser has to examine approved building plans and specifications. In addition, cash inflows and outflows of borrowers need to be analysed. Cash outflows of borrowers need to be supported by the disbursement schedule of the bank loan. As stated by Perera et al., (2007), technical appraisers should verify several factors, such as market values, forced sale values of properties, ground conditions, access roads and prevailing rules and regulations of various authorities. Finally, recommendation of insurance values also becomes a responsibility of technical appraisers.

\section{Conclusions}

This review is done to look at all possible roles and responsibilities of quantity surveyors beyond their traditional duties in building construction industry. This is to create awareness on the extent to which quantity surveyors are involved in various job sectors. A profession in quantity surveying in Malaysia is no longer restricted to the old-style roles and responsibilities in the construction industry. The profession gradually improved due to the drastic growths and complexities of the infrastructure development in our country. The profession also evolves over time with an integration of more enhanced skills and competencies to ensure the readiness of quantity surveyors to survive in recent multi-disciplinary sophisticated businesses. More prospects outside the construction industry are explored leading to other lucrative industries like procurement, oil and gas, green building and banking. From the review, it can be concluded that the challenges that need to be confronted by QS professionals today are greater in order to meet clients' demanding expectations, which in turns forcing them to move forward from their usual roles and responsibilities. This is an important process that the profession need to go through to ensure their visibility in the industry.

For oil and gas, and green building, their basic roles and responsibilities are similar as these sectors are still in the construction parameters. However, quantity surveyors' roles and responsibilities are quite different in banking sector due to the different nature of work. For both oil and gas, and green building sectors, quantity surveyors are responsible in the procurement management. However, in oil and gas sector, the emphasis of quantity surveyors' roles is on offshore work, steel work and piping work. On the other hand, in green building sector, quantity surveyors are required to do cost estimation while taking into consideration all related green building criteria. For banking sector, the roles are rather different as quantity surveyors are required to assess technical appraisals submitted by developers who seek capital to bear the cost of their projects. Therefore, novice quantity surveyors should be aware that they can continue their career in various job sectors, 
INTERNATIONAL JOURNAL OF ACADEMIC RESEARCH IN BUSINESS AND SOCIAL SCIENCES

Vol. 10, No. 10, 2020, E-ISSN: 2222-6990 @ 2020 HRMARS

however they must be willing to equip themselves with knowledge and skills required by the particular sectors that they decide to venture.

\section{Corresponding Author}

Norazlin Mat Salleh, Department of Quantity Surveying, Faculty Architecture, Planning and Surveying, Universiti Tekonologi MARA, 32610 Seri Iskandar, Perak

Email: norazlinmatsalleh@gmail.com

\section{References}

Abdullah, F., \& Haron, I. (2006). Profile of quantity surveying practice in Malaysia. The International Conference of Construction Industry. University Bung Hatta, Padang, Indonesia.

Ashworth, A. (2004). Cost Studies of Buildings. 4th ed. England: Pearson Education Limited

Ashworth, A., \& Hogg, K., (2007). Willis's Practice and Procedure for the Quantity Surveyor. 12th ed. UK: Blackwell Publishing.

Cruywagen, H., \& Llale, J. (2017). The role of quantity surveyors in public-private partnerships in South Africa. South African Journal of Economic and Management Sciences, 20(1), 1-7. https://doi.org/10.4102/sajems.v20i1.1522

Chong B. L. (2014). The Services Required by the Malaysian Construction Industry from Quantity Surveyors and their Implication to Quantity Surveying Graduates. Dissertation Master of Science, Universiti Tunku Abdul Rahman.

Hanid, M., Zakaria, N., Abd Karim, S. B., Abd Wahab, L., Stabal, A. E. R., \& Lee, T. Y. (2007). Beyond the Tradition: Venturing Quantity Surveying Services in the Non-Construction Sectors. Quantity Surveying International Conference 2-14

Jalil, A. A., Mastura, J., Mydin, M. A. O., \& Nuruddin, A. R. (2017). The Application of Procurement Systems in IBS Housing Project. International Journal of Supply Chain Management. 6(4), 299307.

Kalpana, B., \& Rao, T.V., (2017). Role of Commercial Banks in the Economic Development of India International, Journal of Management and Applied Science, 3(4). ISSN: 2394-7926.

Ma, T., \& Luu, H. T. (2013). The Changing Role of Quantity Surveyors in the Green Building Development in South Australia. Doctoral dissertation, School of Natural \& Built Environments, University of south Australia.

Olanrewaju, A. L., \& Anahve, P. J. (2015). Duties and responsibilities of quantity surveyors in the procurement of building services engineering. Procedia Engineering, 123, 352-360.

Perera, B. A. K. S., Hemajith, S. D. M., Ginige, K., \& Amaratunga, D. (2007). Quantity Surveyor as the Technical Appraiser in the Sri Lankan Financial Industry. Built Environment Education Conference (BEECON 2007), January 2007.

Powell, C., (1998). The Challenge of Change. UK: Royal Institutions of Chartered Surveyors.

Odesanya, B. K., \& Ebhohimen, T. E. (2017). Assessment of Participation of Quantity Surveyors in Oil and Gas Projects in Nigeria. Global Journal of Researches in Engineering. 17 (4), 27-39.

Royal Institution Surveyors Malaysia (RISM), (2020). Retrieve from https://www.rism.org.my/quantity surveying-division-qs/

Seah, E. (2009). Sustainable construction and the impact on the Quantity surveyor. In 13th Pacific Association of Quantity Surveyors Congress (pp. 36-48). 
INTERNATIONAL JOURNAL OF ACADEMIC RESEARCH IN BUSINESS AND SOCIAL SCIENCES

Vol. 10, No. 10, 2020, E-ISSN: 2222-6990 @ 2020 HRMARS

Thayaparan, M., Siriwardena, M., Amaratunga, D., Malalgoda, C., \& Keraminiyage, K. (2011). Lifelong Learning and the Changing Role of Quantity Surveying Profession. 15th Pacific Association of Quantity Surveyors Congress, (July), 351-360.

Verster, J. J. (2006). Managing cost, contracts, communication and claims: A quantity surveying perspective on future opportunities. IProceedings of $1^{\text {st }}$ ICEC \& IPMA Global Congress on Project Management, $5^{\text {th }}$ World Congress on Cost Engineering, Project Management and Quantity Surveying. April 5-8, Slovenia, 23-26.

Wao, J. O., \& Flood, I. (2016). The role of quantity surveyors in the international construction area. International Journal of Construction Management, 16(2), 126-137.

Wao, J. O. (2016). Predicting the Future of Quantity Surveying Profession in the Construction Industry. Construction Project Management and Innovation, 6(1), 1363-1374.

Zainudin, N., Palliyaguru, R., \& Nirooja, T. (2006). Career Paths in Quantity Surveying. In: Rameezdeen, R. \& Seneviratne, I., ed. Customizing the Quantity Surveyor to Face Challenges in Year 2020, 26 January 2006 Colombo. University of Moratuwa: Department of Building Economics, 43-58. 